\title{
Bearing of Tax Audit on Tax Compliance and Revenue Generation in Ekiti State
}

\author{
DADA, Raphael Adekola \\ School of Business, University of Aberdeen, UK \\ E-mail: r.dada.18@abdn.ac.uk, aderalph@gmail.com \\ TAIWO, Isaac Babatope \\ School of Management, Universiti Sains Malaysia \\ E-mail: taiwoib@student.usm.my
}

Received: March 1, 2020 Accepted: May 12, $2020 \quad$ Published: June 1, 2020

doi:10.5296/ajfa.v12i1.16850 URL: https://doi.org/10.5296/ajfa.v12i1.16850

\begin{abstract}
The paper examined the impact of tax audit on revenue generation in Ekiti State. The data used for this study was gathered using structured questionnaire administered to 312 staff of the Ekiti State Internal Revenue Service. A regression analysis technique was adopted, and the result revealed that certain per cent of the revenue generated in Ekiti State could be explained by the tax audit; It was also discovered that auditing access, auditing officials, an effective tax audit, non-compliance, audit fieldwork, tax audit control, and corruption affect the revenue generation by $1.188,0.319,0.596,0.148,0.157,0.125$ and 0.002 respectively; the probability value $0.00,0.01,0.00,0.022$ and $0.00<0.05$ showed that auditing access, auditing officials, effective tax audit and incentive were statistically significant at 5 per cent level; the probability of F-statistic value $0.000<0.05$ revealed that the model was appropriate for determining the impact of tax audit on revenue generation in Ekiti State. Thus, the study concluded that tax audit should be embraced as it maximizes the collection of revenue which enables the government to address developmental projects that will benefit its citizenry and also helps in strengthening the businesses of the taxpayer.
\end{abstract}

Keywords: taxation, tax audit, compliance, tax evasion, tax avoidance, back duty. 


\section{Introduction}

There is no gainsaying all over the world that governments at all levels undertake huge public expenditure on behalf of the citizenry for the provision of basic amenities and other social services. In meeting with the constitutional responsibilities, governments thus require a substantial amount of funds which are to be generated across different sources. Among different sources from which governments can generate its revenue/fund are taxes, with the primary purpose of raising revenue to finance government expenditure (Mu'azu 2012). Kanbiro (2018a) described tax revenue as a powerful tool in the hands of government both in developed and developing countries to generate funds/revenues to finance the public expenditure and to stabilize the national economy, and it may also be used to influence expenditure patterns, to redistribute income and wealth among the citizen and also to reflect other social and political objectives. The Nigerian Government (Federal, State \& local) like many other countries are saddled with the responsibility for tax administration, revenue collection and allocation for the developmental program across the tiers of government in the country (Ojonta, 2011). Therefore, this constitutional responsibility reposed in the government at various levels to makes tax a compulsory levy imposed on the salaries, income, profit or wealth of an individual, family, community, partnership, corporate or non-corporate bodies, etc. for the purpose of generating adequate funds to finance public expenditures. As described in the literature, taxation is the inherent power of the government, exercised through the legislation, to impose financial burdens (tax and levy) upon their subjects within its jurisdiction to raise revenues to carry out the government functions (Modugu \& Anyaduba, 2014; Engida \& Baisa, 2014).

Therefore, it is become imperative to note that any individual or establishment that falls within the above income groups, is obliged by the Law of the Federal Republic of Nigeria (LFN) and the law of the respective state's to pay tax, this can be voluntarily or otherwise (Mu'azu 2012). While the amount of revenue government is expected to generate from taxes for its program depends largely on the effective administration of tax law and willingness of the taxpayers to adhere to the relevant tax laws of the land (Kanbiro, 2018b). It is on this process that the issues of returns and self-assessment arose. Every individual or organization liable under the relevant tax law of the country is required to file the returns of their income(s) and other relevant information/matters to the relevant tax authority having the power to assess him or her to tax for the relevant year of assessment, and this is subject to the satisfaction of the returns by the Tax Authority (Olaoye \& Ekundayo, 2019; Oyebanji, 2006). However, it is expedient for the relevant tax authority to review and verify self-assessed tax filed by individual taxpayers by way of an audit and, or investigation (KPNG, 2017), this exercise was put in place like control to reduced non-compliance (Ojo, 2016; Olaoye \& Ekundayo, 2019). Thus, if this professional examination was not in place as control over the taxpayer; it will be difficult for the government to actualize its aims and objectives. Meanwhile, Opoku (2015) defines a tax audit as an investigation conducted into the financial record of the taxpayer by Revenue Service officials to verify the compliance of the taxpayer. In the same manner KPMG (2017) describe tax audit as a review of tax payer's records which covers the disclosure of all significant accounting practices employed in the course of preparing the financial report which includes; statement of financial position, statement of profit or loss account and other related accounts and schedules 
which form part of financial reports to ascertain compliance with the relevant tax law. Also, further information is required for the computation of assessable income as well as to ensure that tax provision is complied with. Adeniran, Alade, and Oshode, (2013) described that tax audit as a financial audit which involves the gathering and processing of taxpayers information to determining the level of their compliance with tax laws of the territory. Kircher (2008) in its definition says, tax audit as "an examination of the tax report of an individual or organizations by the relevant tax authorities to ascertain their compliance with applicable tax laws and regulations of the state". He further said that a tax audit is a review where the internal revenue service set to confirm that the self-returns filed by the taxpayer is appropriate, adequate and correct. Meanwhile, Frank (2010) concludes that designing an effective tax audit policy can have an influence on production/revenue generation decisions of the firms and government, respectively.

The increase in the government running cost coupled with government willingness to meet infrastructures deficit and socials needs of the citizenry has left various governments with no option other than to formulate strategies that will improve their revenue base (Oladele, Uduma \& Aderemi, 2013). Over the years, Nigerian had experienced economical unruliness and political instability. The national economy became totally cripple due to over-dependence on the oil revenues, which eventually resulted in the serious decline in crude oil price in the world market. This led the country into a recession as a result of this, taxation is now regarded as a critical and best alternatives source of revenues to augment whatever individual state received from central government purse to finance their project as a result of dwindling in the distributable revenues accrued to the federation accounts (Afuberoh \& Okoye, 2014; Sokenu, 2016). For the State governments to meet up with their constitutional functions, there is a need to generate adequate and more revenue from internal sources, this has, therefore, become a matter of urgency and imperatively importance. This need highlights the enthusiasm on the part of state governments and even the federal government agent to look for both the old and new sources of revenue or to become more aggressive and innovative in the manner at which the revenue has been collected from existing sources (Afuberoh \& Okoye, 2014; Dada, Adebayo \& Ogunmakin, 2017). Achieving this target will allow the government to broaden the scope of tax coverage and sustained the continual compliance by the taxpayer through effective legislation, e.g. tax audit and investigation (KPMG, 2017). Mu'azu (2012) agreed that tax audit reduces the problems of tax evasion while Onoja and Iwarere (2015) revealed that, tax audit had significantly impacted revenue generation in Federal Inland Revenue Service. The extent of the impact of the tax audit on tax compliance and revenue generation is not well understood and probably not been felt across the state of the federation due to the scare/few kinds of literature addressing the impact on the state government most especially Ekiti State to the best of the authors' knowledge. Therefore, examining the tax audit impact on tax compliance and revenue generation in Ekiti State and the factors that influence tax compliance are the primary purpose of this study. Therefore, the paper is organized in five parts. In addition to the introduction, other parts of the paper include the conceptual framework which comprised revenue and tax audit concept, empirical review, research methodology and discussion, and the last section is conclusion and recommendation. 


\section{Macrothink}

\section{Literature Review}

\section{Conceptual Framework}

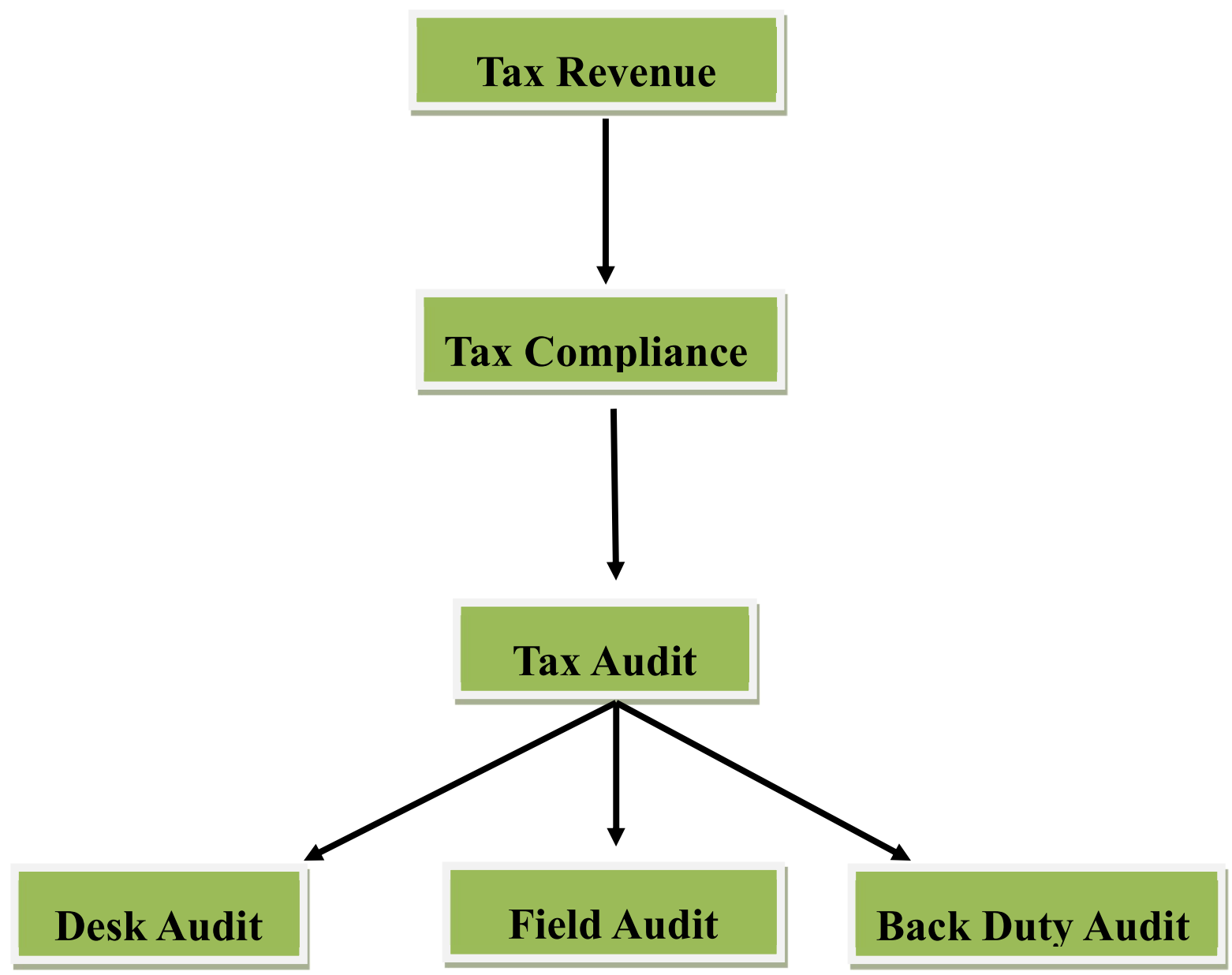

\section{Author's Model (2020)}

Tax Revenue: The term revenue generation all over the world of which Nigeria is not exempted is derived from tax and non-tax sources. Dada et al. (2017) stated that revenue is a general term that encompasses all monetary receipts accrued both from the tax and non-taxes sources such as fees, fines, sales of government properties, grants and contributions, etc., as these constitute the live wire of any government. Meanwhile, Opoku (2015) defined tax as the compulsory levying on the public by the government through the relevant tax authorities having tax jurisdiction to exercise power to collect taxes, to defray the cost of their activities. Olatunji, Olaleye, and Adesina (2001) define tax is a system of imposing a compulsory levy on all incomes, goods, services, and properties of individuals, partnerships, trustees, executors and companies by the government. Tax is a certain percentage of money that you must pay to the government according to your income, property, goods which are used to cater for public services/demand and perform other social responsibilities, which there is no direct return to the taxpayers for obliged other than the general benefit (Tilahun 2018). Therefore, taxation is a compulsory level or transfer of resources from the private sector to the public sector or and 
levied based on the criterion and without reference to specific benefits received to execute the nation's economic and social objectives (Dada et al., 2017; Olaoye \& Ekundayo, 2019). Taxation primarily aimed at generating revenue for the government to cater to national or state expenditure as the case may be (Mu'azual 2012). While non-taxes are the revenue accrued to the government treasury other than tax and which is supported by the law of the Federation. Ojo (2009) had shown the reasons why people have to pay tax to enable the government to discharge its constitutional functions. The rationale for imposing taxes in a market economy such as Nigeria may not be far from the government responsibilities which include the followings as stated by Ariwodola (2001), Dinku and Alamirew (2018), Olatunji, et al. (2001): redistribution of income and wealth; promotion of social and economic welfare; economic stability and growth; provision of public goods and services, pure public goods are the one that displays the following characteristics: displays zero marginal cost, that is, no extra cost is incurred in supplying the good to more than one person, individuals cannot be excluded from consuming the good, even if they have no desire for it, all members of society must consume it at the same amount; it cannot be rejected. For example, law and order, peace and security, good access road, pipe born water, etc. therefore, the ability of the government to fulfil these constitutional functions depend heavily on the willingness and readiness of the citizen to respond to this civic right/duty.

Tax Compliance: Tax compliance can be explained as any strategy put in place to prevent tax evasion and avoidance. According to Kircher (2008) tax compliance is the ability of a tax liable body (individuals or corporate bodies) to submit accurate, comprehensive and satisfactory tax returns in conformity with tax laws and provisions of the state to the relevant tax authority within their jurisdiction for tax assessment without been coerce. Palil and Mustapha (2011) also describe tax compliance as taxpayers' ability and willingness to comply with relevant tax laws provision which is determined by ethics, culture, legal environment and other situational factors at a particular time and place. Similarly, tax compliance is also defined by tax authorities as to the ability and willingness of taxpayers to cooperate or comply with tax laws by declaring their true, correct and total income for the year and pay the correct/right amount of tax on time to the relevant authority (IRS, 2009; ATO, 2009; IRBM, 2009; Oladipupo \& Obazee, 2016; Olaoye \& Ekundayo, 2019). Government effort increases the tax compliance among the tax liable bodies, introduced a self-assessment approach. Self-assessment was introduced effect from the 1996 year of assessment to encourage voluntary declaration of incomes and compliance, to reduce tax evasion and enable taxpayers to make returns within the stipulated time limit. It is the most convenient method to ensure prompt payment of tax, as it enables the taxpayer to compute their tax and capital allowances liability and remitted same to the government purse within the time frame (Olaoye, 2008; Olatunji et al., 2001; Verboon $\&$ Van Dijke, 2014). Despite the government effort through the relevant tax authority's to encourage tax compliance among the taxpayers, non-compliance still persist which is "the failure of the tax liable bodies either intentionally or non-intentionally, deliberate or not deliberate (avoidance or evasion) to meet their tax obligations to the relevant tax agent (Jaidi, Noordin \& Kassim, 2013; Kinsey, 1985). Non-compliance does happen when taxpayers' cleverly capitalized on tax law loopholes to reduce their tax burden, and other factors could be carelessness, such as forgetting to pay their tax, tax calculating error and even more critical 
factor is the taxpayer illiteracy and information asymmetric about tax law. On the other hand, tax fraud or a crime is a type of non-compliance willfully done by the taxpayers against the tax law (Jaidi, Noordin \& Kassim, 2013; KPMG, 2017). In other to reduced and at the same time fight the menace of non-compliance, government at a different level and in various state introduce the concept of a tax audit to enforced compliance.

Tax Audit: Auditing is an independent examination and expression of opinion on the financial statement of an enterprise by an external auditor in accordance with his terms of engagement and compliance with statutory regulation and professional requirements (Oladipupu, 2005), while on the other hand, taxation as been described by some authors, is the inherent power of the state, exercised through the legislature, to impose financial burdens upon tax liable citizen within its jurisdiction for raising revenues to carry out the constitutional duties of government (Modugu \& Anyaduba, 2014; Palil \& Mustapha, 2011; Ojo, 2016). However, this constitutional duty has been frustrated by tax evasion and tax avoidance, and in other to combat this ugly phenomenon, government at a various level most especially in Nigeria have introduced a tax audit into their tax system (Modugu \& Anyaduba,2014; Olaoye, Ayeni \& Alaran-Ajewole, 2017). According to OECD (2006), a tax audit is described as an examination of the record to satisfy whether a taxpayer has correctly disclosed and reported their tax liability and fulfilled other obligations. In another view, Adeniran et al. (2013), opined that tax audit just like financial audit involves the review of taxpayer financial records in other to determine the level of compliance with tax laws of the territory. For a successful audit, the auditor must organize his work in such a way that the assignment is accomplished economically and efficiently without additional cost. Corroborating this Olaoye and Ekundayo (2019) define tax audit as "an examination of an organization or individual's tax report by the relevant tax authorities to ascertain compliance with applicable tax laws and regulations of the state". He further stated that tax audit is an exercise of internal revenue service officer to confirm the correctness and accuracy of the figure put up on your tax return (Mukhtar, Kerosi and Ondabu, 2015). Tax audit is best carried out either as desk audit, field audit or back duty audit.

Desk (or Office) Audit: this is the type of tax audit, where the whole activity of the audit exercise takes place within the premises and confines of the office of the tax officials. In this situation, the tax office may request the taxpayers to provide or forward some additional documents as a matter of statutory to his office to enable him to clear some grey area in the self-assessment returns submitted with the revenue officer. In this type of audit, revenue officer does not mandate nor required to the notified taxpayer of the ongoing exercise. He gets to know this when the letter(s) are written to him requested that certain documents be forwarded or should appear to give explanations on a certain issue. The essence of the exercise is to ensure some level of compliance with tax laws, rules and regulations as well as carry out administrative checks or task on returns submitted (NUON, 2015; Adediran et al., 2013).

Field Audit: A field audit is elaborate and comprehensive than a desk audit. It is usually carried out outside the Tax Authority's office in the taxpayer's office premises. The essence of carrying it out in the taxpayer's premises is to enable the tax auditor's carry out the examination of necessary documents and also obtain appropriate information directly from the officials of the business (Ojo, 2016; Olaoye \& Ekundayo, 2019). This takes more time, and more basic 
documents are always required. Some documentation can also be taken down to the office for detailed verification while some may not. The scope or depth of this exercise largely depends on the outcome of the desk audit task carried out by the tax auditor as well as the risk factors of the audit exercise. Special attention will be paid to those items likely to have high tax yield potentials. The tax audit is normally carried out as a result of the back duty audit exercise (Badara, 2012; Ojonta \& Iwarere, 2015).

Back Duty Audit: According to Olaoye (2008), Olatunji, et al. (2001) and Ariwodola (2000). Back duty audit may be instituted against the taxpayers when the following case(s) occurs: failure to fully disclose or include all income(s) or earnings in the return files or submitted to the revenue office; the doubtful claim of capital allowance in respect of current or previous year; conspicuous reduction in the reported profit in the returns files in the tax office or where the tax charged is less than what it ought to be. The charging of back duty audit on a taxpayer can either be a routine or random, which may be as a result of the above reason. It is an exercise required of the relevant tax authority to ensure that the exact amount due to the government is duly collected.

\section{Causes of Tax Evasion and Tax Avoidance in Nigeria}

Tax evasion according to Ifere and Eko (2014), Jarunee (2010), Uadiale, Fagbemi and Ogunleye (2010) is a deliberate, willful practice or an outright dishonest action, whereby the taxpayer reduced his tax liability through the use of illegal means. While Tax avoidance refers to the arrangement through which a person acting within the letter of the law reduces his true tax liability, infringing in the process both the spirit and intention of the law (Fatoki, 2014). Kay (1980) said that tax avoidance takes place when the facts of the transaction are admitted, arranged or presented in a way that the resulting tax treatment will differ from the intended by the relevant legislation. Thus, while tax avoidance is within the ambit of the law and legal, tax evasion is illegal and is a criminal offence punishable under the law (Oladele et al., 2013; Arowomole and Oluwakayode 2006).

Tax evasion is accomplished by a willful practise and deliberate act of omission or commission which amounted to criminal acts under the tax laws of a nation, and these acts include failure to pay tax, e.g. withholding tax, value-added tax etc. failure to submit returns, the omission of items from returns, claiming relief (in Personal Income Tax; for example, unborn children, non-existed dependant), understating income, documenting fictitious transactions, overstating expenses, Failure to answer queries (Farayola, 1987; Ojo, 2016; Olaoye \& Ekundayo, 2019). According to Uadialeet et al. (2010), Kastlunger, Kirchler, Mittone, and Pitters (2009), other causes of non-compliance are corruption in a public institution, inadequate awareness and tax education, misappropriation of taxes received, lack of adequate enforcement for default, ignorance of the tax authority, the proliferation of taxes, inequitable distribution of income, loopholes in the tax laws, absence of 'Quid Pro Quo,' i.e. value given in return (by the government) for taxes paid, high level of illiteracy, information asymmetric, lack of proper record-keeping and high tax rates. KPMG (2017), In other to put strategies in place to resolve tax dispute between the tax authority and the liable taxpayers, to maintain a strong mechanism to deal with tax avoidance and evasion techniques which are available to various organizations, 
but are susceptible to tax abuse and to bring defaulter taxpayers to the net of tax authorities tax audit was introduced.

\section{Objectives of Tax Audit}

According to Mukhtar, Kerosi and Ondabu (2015); NOUN, (2015); Erard (1994) cited in Mu'azu (2012) the objectives of tax audit excercise are to enable the tax auditors to determine whether or not: adequate accounting books and records exist for determining the taxable profits or loss of the taxpayer and consequently review the tax payable; the tax computations submitted to the tax authority by the respective taxpayer agreed with the underlying records; all applicable tax legislations have been observed and complied with; there is a provision of an avenue to educate taxpayers on various provisions of the tax law; discourage tax evasion; detect and correct accounting or arithmetical errors in tax returns; provide feedback to the decisions maker on various provisions of the law and recommend possible changes; identify cases involving tax fraud and recommend them for proper investigation; forestall taxable persons' failure to render tax returns; prevent taxable persons' from rendering incomplete or inaccurate returns; encourage voluntary compliance among the tax payer which is one of the strong reasons in support of the self-assessment scheme.

\section{Tax audit officer and Taxpayer responsibilities}

The following are the responsibilities of both tax official and taxpayer as stated in the Beyene, Deresse and Mathewos (2019), Biber (2010), Modugo and Anyaduba (2014), OECD (2006) Olaoye and Ekundayo (2019).

\section{Responsibilities of Audit Officer}

A tax auditor is expected to carry out the tax audit exercise in the following manner: be professional and courteous; knowledgeable and be fair in administering tax laws; be honest and trustworthy; cooperative and be a willingness to give advice and guidance to the taxpayer at all time; ensure that the exercise is carried out as expected with minimum disruption to the taxpayer business or activities; request for documents, records and books of accounts and any other pieces of information that are relevant to the audit assignment only; ensure that the rights and interest of taxpayers, tax agents and documents are safeguarded

\section{Responsibilities of Taxpayer}

According to Modugo and Anyaduba (2014), OECD (2006), taxpayers are expected to be courteous, fair and honest, they must ready to provide reasonable facilities, information and assistance during an audit assignment. This includes giving access to tax audit officers to the business premises, providing information and making available relevant documents and records required for the purpose of the exercise. Promptly respond to all queries. If the questions raised are ambiguous, he must seek clarification from the tax audit official without delay. Also, the taxpayer may also be a query on personal matters such as personal expenses, savings, bank accounts, assets, etc. Taxpayers can request that their tax agents be present during an interview in order to facilitate the audit process. The taxpayer is not expected to suspend or stop business activities during the audit assignment. Therefore, giving full cooperation and 
support to make sure that the assignment does not unnecessarily prolonged or linger and ensure that any disruption to the business is kept at a minimum. Furthermore, taxpayers are not allowed under any law to transact business with the audit officer while the exercise lasts other than on normal terms. Taxpayers should avoid making payment to audit officers. Any tax payment arising out of an audit adjustment must be payable directly to the official revenues bank account at the designated bank or any Collection Branch of the internal revenue service.

\section{Empirical Review}

Mu'azu (2012) studied the effect of tax audit on tax compliance in Nigeria a case of Bauchi State Board of Internal Revenue, employed primary source to obtained data from the staff of Bauchi State Board of Internal Revenue and used the simple percentage to analyze the data, and the finding revealed that tax audit reduces tax avoidance and tax evasion, that taxpayers do not usually cooperate with tax audit officers during the exercise.

Adediran, Alade, and Oshode (2013) examined the impact of tax audit and investigations on revenue generation in Nigeria, obtained data through structure questionnaire from the respondent, tested the hypotheses with Pearson Correlation Coefficient using SPSS output data, the study concluded that Tax audit and investigations could increase the government revenue base and can also stamp out the incidents of tax evasion in the country. He recommended that Tax audit and investigations should be carried out often and must be thorough in accomplishing its task of increasing the government revenue base and stamping out tax evasion in the country.

In the same manner, Ibrahim, Yusuf, and Bello (2014) investigated the contribution of tax audit and the resultants investigation to the sustainable development of the Nigerian economy and concluded that the practising accountants should follow the fundamental principles of professional ethics while rendering consultancy services since they often act for taxpayers in their dealings with the relevant tax authority.

Kennedy and John (2014) investigated the impact of tax audit on tax compliance in Nigeria and concluded that the probability of being audited, perception on government spending, penalties and enforcement, the joint effect of tax audit and penalties tend to influence tax compliance in Nigeria significantly.

Wuyah, Aku and Ahmad (2018) study the Impact of Tax Audit and Investigation on Value Added Tax Generation in Kaduna State used percentages and graphs and Pearson Correlation Coefficient (SPSS) to analyze the data collected through the use of a questionnaire. The result of the findings revealed that Tax audit and investigations have the potential to increase valueadded and reduce VAT evasion. While Dickson (2014) evaluate the impact of tax reform on federal revenue generation in Nigeria concluded that tax reform by improving the tax system and reducing tax burden enhances the ability of the government to generate more revenue.

Afuberoh and Okoye (2014), examined the effect of taxation on revenue generation in Nigeria and recommends among others that Well-Equipped DataBase (WEDB) on all taxpayers should be created by the Federal, State and Local Governments for the purpose of identifying all possible sources of income of taxpayers for tax purpose however the tax collection processes must be free from corruption. Meanwhile, Onoja and Iwarere (2015) examined the effects of 


\section{Mll Macrothink}

Asian Journal of Finance \& Accounting

ISSN 1946-052X

2020, Vol. 12, No. 1

tax audit on revenue generation: Federal Inland Revenue Service Abuja; generated data through a questionnaire administered to the respondent while they employed Analysis of Variance (ANOVA) to analyse the data, the findings revealed that tax audit has significant impacts on revenue generation by Federal Inland Revenue Service while tax audit has a positive effect with the revenue generation by Federal Inland Revenue Service.

Oladipupo and Obazee (2016) in their study investigated the impacts of taxpayers' knowledge and penalties on tax compliance of a small and medium enterprise in Nigeria, they employed the use of survey research design, the data gathered through the administered questionnaire were analyzed using the OLS regression method, and the results of the finding revealed that tax knowledge had a significant positive impact on tax compliance while tax penalty had an inconsequential impact on tax compliance. Thus, the study concluded that tax knowledge has a tendency to promote tax compliance among the taxpayer than the tax penalty.

\section{Methodology}

The population of the study is three hundred and twelve (312) from Ekiti State Internal Revenue Service (SIRS) in their staff disposition list as of 2016. The data source for this study was generated through the primary sources with the use of questionnaires administered to the staff of the Ekiti State Internal Revenue Service (SIRS) while secondary sources were obtained from the review of several publications that are relevant to the study. Two hundred and sixty-five (265) questionnaires were properly filled and returned. The questionnaires were then analyzed using ANOVA. The analysis of the results is presented below.

\section{Interpretation}

\begin{tabular}{|l|r|r|r|r|}
\hline \multicolumn{5}{|c|}{ Model Summary } \\
\hline Model & R & R Square & $\begin{array}{c}\text { Adjusted R } \\
\text { Square }\end{array}$ & $\begin{array}{c}\text { Standard } \\
\text { Error of the } \\
\text { Estimate }\end{array}$ \\
\hline 1 & $.794^{\mathrm{a}}$ & .630 & .618 & 1.09993 \\
\hline
\end{tabular}

The table shows that the correlation coefficient ( $\mathrm{r}$ ) was 0.749 . It implies a positive correlation or relationship between independent variables and dependent variables.

The R-square, which shows the overall explanatory power of the model, reveals that independent variables explain about $63 \%$ of the systematic variation of the dependent variable while the remaining $37 \%$ was due to other variables outside the regression model. 


\begin{tabular}{|l|l|r|r|r|r|r|}
\hline \multicolumn{7}{|c|}{ ANOVA } \\
\hline \multicolumn{2}{|l|}{ Model } & $\begin{array}{c}\text { Sum of } \\
\text { Squares }\end{array}$ & \multicolumn{1}{c|}{ Df } & $\begin{array}{c}\text { Mean } \\
\text { Square }\end{array}$ & F & Sig. \\
\hline \multirow{3}{*}{1} & Regression & 527.318 & 8 & 65.915 & 54.482 & $.000^{\mathrm{b}}$ \\
\cline { 2 - 8 } & Residual & 309.723 & 256 & 1.210 & & \\
\cline { 2 - 8 } & Total & 837.042 & 264 & & & \\
\hline
\end{tabular}

The table above shows the overall significance of the test, which is reported as follows; $\mathrm{F}$ ( 8 , 248) 54.482, $\mathrm{P}<0.05$. The degree of freedom of the regression is 8 ; also, the degree of freedom of the residual is $256, \mathrm{~F}$ calculated is 54.482 and significant value or P-value is 0.000 . This reveals that there is a significant effect of independent variables on the dependent variable.

\begin{tabular}{|c|c|c|c|c|c|}
\hline \multicolumn{2}{|c|}{ Coefficients } \\
\hline \multirow{2}{*}{ Model } & \multicolumn{2}{c}{$\begin{array}{c}\text { Unstandardized } \\
\text { Coefficients }\end{array}$} & $\begin{array}{c}\text { Standardized } \\
\text { Coefficients }\end{array}$ & t & Sig. \\
\cline { 2 - 6 } & B & Std. Error & Beta & \\
\hline (Constant) & 16.603 & 1.477 & & 11.243 & .000 \\
\hline Auditi_inf_acces & 1.188 & .136 & .455 & 8.751 & .000 \\
\hline inadeq_tax_officio & .319 & .094 & .204 & 3.374 & .001 \\
\hline effect_tax_audit & -.596 & .108 & -.281 & -5.517 & .000 \\
\hline Non_compliance & .148 & .111 & .062 & 1.335 & .183 \\
\hline Audit_field_work & .157 & .068 & .103 & 2.297 & .022 \\
\hline tax_audit_control & .125 & .095 & .057 & 1.312 & .191 \\
\hline Corruption & .002 & .079 & .002 & .027 & .979 \\
\hline Incentive & .389 & .075 & .250 & 5.149 & .000 \\
\hline
\end{tabular}

a. Dependent Variable: revenue generation

The Regression above is a multiple regression, the model of the equation is stated as; 


\section{$\mathrm{Y}=16.6+1.188 \mathrm{AUD} \_\mathrm{ACC}+0.319 \mathrm{IND} \_$OFF-0.596EFF_AUD+ \\ $0.148 \mathrm{NON}$ _COM+0.157AUD_WORK $+0.125 \mathrm{TAX}$ _CON+ $0.389 \mathrm{COR}$}

The result presented above shows the effect of independent variables on the dependent variable. The explanatory variables include auditing access, auditing officials, effective tax audit, noncompliance, audit fieldwork, tax audit control, and corruption, while the explained variable is revenue generation. The signs of the coefficients of these variables, the positive signs depict a positive relationship between the variables while the negative sign depicts the otherwise. The constant (16.603) represents the value that revenue generation will assume if all the variables are zero. It was also discovered that $1 \%$ increase in auditing access, auditing officials, effective tax audit, non-compliance, audit fieldwork and, tax audit control and corruption other things being equal, will increase revenue generation by $1.188,0.319,0.596,0.148,0.157,0.125$ and 0.002 respectively and vice-versa. The p-value checks the significant level of the variables, and the analysis revealed that auditing access, auditing officials, effective tax audit and incentive were significantly correlated to revenue generation with a p-value of $0.00,0.01,0.00,0.022$ and 0.00 respectively. On the other hand, non-compliance, tax audit control, and corruption were not significantly correlated to revenue generation with a p-value of $0.183,0.191$ and 0.070 , respectively.

\section{Discussion, Conclusion, and Recommendation}

\section{Discussion}

The study revealed that tax audit was significantly correlated to revenue generation in Ekiti State. This implies that tax audit ensures proper filing of appropriate and accurate returns and computation in taxpayer's records; tax audit reduced tax evasion and tax avoidance and ensures compliance with tax laws, rules, and regulations by the taxpayers. The study revealed that tax audit has a positive relationship with the revenue generation in Ekiti State. This means that 1\% increase in tax audit (increase in auditing access, auditing officials, effective tax audit, noncompliance, audit fieldwork and, tax audit control and corruption) other things being equal, will increase revenue generation by $1.188,0.319,0.596,0.148,0.157,0.125$ and 0.002 respectively and vice-versa. This was in consonant with Onoja and Iwarere (2015); Olaoye and Ekundayo (2019) who concluded that tax audit has significant effects on revenue generation by Federal Inland Revenue Service and tax audit has a positive relationship with the revenue generation by Federal Inland Revenue Service.

\section{Conclusion}

The study objective is to investigate the effect of the tax audit on the revenue generation in Ekiti State. The study went further to access the relationship between the tax audit and revenue generation in the State. The study concluded that tax audit should be embraced as it maximizes the collection of revenue which enables the government to address developmental projects that will benefit its citizenry and also helps in strengthening the activities of the taxpayer. 
Recommendation

The study recommended that the government should focus more on tax audit now that the oil revenue accrued to the federation account is dwindle as a result of global drop in crude oil prices; sufficient mechanism should be in place to check and monitor the staff of the tax audit department to minimize the level of corruption and enhance the effectiveness of the tax audit; government should give autonomy to Tax Audit Department to enable them to carry out their responsibility effectively as specified in established law/edict; States should ensure that the officer conducting the tax audit are tax professional; tax audit staff should have full knowledge of modern audit tools like Computer Aided Audit Tools (CAATs) to enhance performance and maximum tax revenue generation; tax audit should be carried out on a routine basis to ensure that taxpayers file the correct returns and that actual revenue collected was remitted to the government coffer.

\section{References}

Adediran S. A., Alade S. O., \& Oshode A. A. (2013). The Impact of Tax Audit and Investigation on Revenue Generation in Nigeria. European Journal of Business and Management, 5(26), 171-176.

Auberon, D., \& Okoye, E. (2014). The Impact of Taxation on Revenue Generation in Nigeria, International Journal of Public Administration and Management Research, 2(2).

Ariwodola J. A. (2001) Companies Taxation in Nigeria Including Petroleum Profit Tax, $\left(4^{\text {th }}\right.$ ed.) JAA Nigeria Ltd, Ebute Meta, Nigeria.

Badara, M. S. (2012). The Effect of Tax Audit on Tax Compliance in Nigeria (A Study of Bauchi State Board of Internal Revenue). Research Journal of Finance and Accounting, 3, 7480.

Dada, R. A., Adebayo, I. A., \& Ogunmakin, A. A. (2017). An Assessment of Revenue Mobilization in Nigeria Local Government: Problems and Prospects. Archives of Business Research, 5(9), 119-127. https://doi.org/10.14738/abr.59.2885

Beyene, Y. N., Deresse, M. L., \& Mathewos, W. (2019). Effectiveness of Tax Audit: A Study in Kembata Tembaro Zone, Southern Ethiopia. International Journal of Commerce and Finance, 5(1), 34-50.

Biber, E. (2010). Revenue Administration: Taxpayer Audit-Development of Effective Plans. Technical Notes and Manuals 10/03. International Monetary Fund, Fiscal Affairs Department. https://doi.org/10.5089/9781462306145.005

Dickson, E. O., \& Rolle, R. A. (2014). The Impact of Tax Reform on the Revenue Generation In Nigeria. Journal of Policy and Development Studies, 9(1), 92-108. https://doi.org/10.12816/0011185

Erard B. (1994). Taxation with representation: An analysis of the responsibility of tax practitioners in tax compliance. J. Public Econ., 52(1), 163-197. https://doi.org/10.1016/00472727(93)90019-P 
Farayola, G.O. (1987). Guide to Nigerian Taxes, Lagos: All Crowns Nig. Ltd.

Fatoki, J. O. (2014). An Empirical Study of Tax Evasion and Avoidance: A Critical Issue in Nigeria Economic Development. Journal of Economics and Sustainable Development, 5(18), 22-26.

Frank, C. (2010). Tax Compliance by Firms and Audit Policy. University of Adelaide, London.

Ibrahim, A., Yusuf, O. \& Bello, F. (2014). The Contribution of Tax Investigation and Tax Audit to the Sustainable Development of the Nigerian Economy: Proceedings of the Multidisciplinary Academic Conference on Sustainable Development, 2(1), 10-11.

Ifere, E. O., \& Eko, E. O. (2014). Tax Innovation, Administration and Revenue Generation in Nigeria: Case of Cross River State. International Journal of Social, Behavioral, Educational, Economic, Business and Industrial Engineering, 8(5), 1603-1609 https://waset.org/1999.10/9998908

Inland Revenue Services. (2009). Taxpayer Audit: a guide to Inland Revenue's Taxpayer Audit Programme, Malaysia.

Kastlunger B, Kirchler E, Mittone L, \& Pitters J. (2009). Sequences of tax compliance, tax audits, and taxpaying strategies. J. Econ. Psychol., 30, 405-418. https://doi.org/10.1016/j.joep.2008.10.004

Kay, G. (1980). The Anatomy of Tax Avoidance in the Income Distribution: Limits to Redistribution. Proceedings of the 31st Symposium of the Colston Research Society,

Kircher, E. E. (2008). Enforced versus Voluntary Act of Tax Compliance: The Slippery Framework. Journal of Economic Psychology, 29(2), 210-225. https://doi.org/10.1016/j.joep.2007.05.004

LHDN. (2007). Lembaga Hasil Dalam Negeri Annual Report.

Modugu, K. P., \& Anyaduba, J. O. (2014). Impact of Tax Audit on Tax Compliance in Nigeria International Journal of Business and Social Science, 5(9), 207-215.

Mu'Azu, S. B. (2012). The Effect of Tax Audit on Tax law Compliance in Nigeria (A Study of Bauchi State Board of Internal Revenue). Research Journal of Finance and Accounting, 3(4), 74-80.

Mukhtar, A. E., Kerosi, E., \& Ondabu, I. T. (2015). Relationship between Tax Compliance Barriers and Government's Revenue Generation at Gobonimo Market in Somaliland. International Journal of Business Management and Economic Research (IJBMER), 6(6), 380399.

NOUN. (2015). Advanced Taxation. Published by National Open University of Nigeria

Ojo. (2016). The Impact of Tax Audit on the Compliance Level of Taxpayers in Kwara State. Unpublished Master's Thesis, University of Ilorin, Ilorin. 


\section{MInstitute Macrothink $_{\text {Int }}$}

Asian Journal of Finance \& Accounting ISSN 1946-052X

Ojont, B. A. (2011). Tax Audit And Investigation In Enugu State of Nigeria. A dissertation presented in partial fulfilment of the requirement for the award of master of science (M.Sc) in Accountancy, Department of accountancy, Faculty of business administration, University of Nigeria, Enugu campus

Oladele, R., Uduma, S. A. U., \& Aderemi, A. A. (2013). Revenue Generation and Engagement of Tax Consultants in Lagos State, Nigeria: Continuous Tax Evasion and Irregularities. European Journal of Business and Social Sciences, 1(10), 25-35,

Oladipupo, A.O., \& Obazee, U. (2016). Tax Knowledge, Penalties and Tax Compliance in Small and Medium Scale Enterprises in Nigeria. iBusiness, 8, 1-9. https://doi.org/10.4236/ib.2016.81001

Olaoye, C.O., \& Ekundayo, A.T. (2019). Effects of Tax Audit on Tax Compliance and Remittance of Tax Revenue in Ekiti State. Open Journal of Accounting, 8, 1-17. https://doi.org/10.4236/ojacct.2019.81001

Olaoye, C. O., Ayeni-Agbaje, A. F., \& Alaran-Ajewole, A. P. (2017). Tax Information, Administration and Knowledge on TaxPayers' Compliance of Block Moulding Firms in Ekiti State. Journal of Finance and Accounting, 5, 131-138. https://doi.org/10.11648/j.jfa.20170504.12

Onoja, M. L., \& Iwarere, T. H. (2015). Effects of Tax Audit on Revenue Generation: Federal Inland Revenue Service, Abuja Experience. Journal of Good Governance and Sustainable Development in Africa (JGGSDA), 2(4).67-80

Opoku, J. S. (2015). The Role of Tax Audit In Revenue Mobilization In Ghana Revenue Authority. A Thesis Submitted to the Department of Accounting and Finance, Kwame Nkrumah University of Science and Technology (KNUST), in partial fulfilment of the requirement for the degree of Master of Business Administration (MBA) Accounting Option

OECD. (2006). Strengthening Tax Audit Capabilities: General Principles and Approaches. OECD Information Note

Ojo, S. (2009). Fundamental Principles of Nigeria Tax, Sagribra Lagos, Tax Publications

Oyebanji, J.O. (2006). On the Principles and Practice of Taxation in Nigeria (3rd ed.). Frontline Publishers Adesola, Ibadan, Nigeria.

Palil, M. R., \& Mustapha, A. F. (2011). Tax audit and compliance in Asia: A case study of Malaysia. European Journal of Social Sciences, 24(1), 7-32.

The IRBM (2009). Annual Report 2005: Inland Revenue Board, Malaysia.

Uadiale, O.M., Fagbemi, T. O., \& Ogunleye, J. O. (2010). An Empirical Study of the Tax Evasion Relationship between Culture and Personal Income in Nigeria. European Journal of Economics, Finance and Administrative Sciences, p. 116-126. 
Verboon, \& Van Dijke. (2014). A Self-Interest Analysis of Justice and Compliance: How Distributive Justice Moderates the Effect of Outcome Favorability. Journal of Economic Psychology, 28, 704-727. https://doi.org/10.1016/j.joep.2007.09.004 